\title{
The Influence of Temperature and Irradiance on Performance of the Photovoltaic Panel in the Middle of Iraq
}

\author{
Moafaq K.S. Al-Ghezi*, Roshen T. Ahmed, Miqdam Tariq Chaichan \\ Energy and Renewable Energies Technology Center, University of Technology-Iraq, Baghdad, Iraq
}

\begin{abstract}
The photovoltaic (PV) panels are expected to be the most important systems to meet global energy demand by converting solar energy into electricity. The main obstacle to the widespread deployment of the PV systems its the limited efficiency, which are greatly affected by the solar radiation and the operating temperature. The full knowledge of the performance, efficiency and output power of photovoltaic modules and the extent of their change with the fluctuations of solar radiation and temperature is necessary to determine the optimal size of the system and avoid the financial risks of the project. This paper investigated numaricaly and experimentaly the influence of operating temperature and solar radiation on the output power and efficiency of polycrystalline PV panels in Baghdad-Iraq. The PVsyst software was used to simulate a model implementing simulation results presented the impact of variations temperature and solar radiation in the curves of I-V, P-V and efficiency. In order to verify the reliability of the simulated results with experimental ones, several measuring devices have been used to conduct field experiments in the outdoor conditions. It were used to determine the characteristics and performance of a $120 \mathrm{~W}$ polycrystalline PV panel for different ranges of solar radiation and operating temperature. The simulation results showed that the current, voltage, output power and efficiency increased with increasing solar radiation, while they decreased with increasing temperature except the current that was increased. The experimental and simulated results were identical in terms of the effect of temperature and solar radiation on the current, voltage, output power and efficiency of the PV panel. The experimental tests showed that when the temperature is increased by $1^{\circ} \mathrm{C}$, the current was increased by about $0.068 \%$, the voltage decreased by $0.34 \%$, the output power decreased by $0.489 \%$ and the efficiency decreased about $0.586 \%$. The experimental results displayed that the parameters of the PV panel under real operating conditions behave differently than in the standard test conditions (STC), as they are strongly affected by weather fluctuations in terms of temperature and solar radiation.
\end{abstract}

Keywords: Solar PV panel, Irradiance, PV temperature, Polycristalline, Baghdad-Iraq.

Article History: Received: 30 th Dec 2021; Revised: $5^{\text {th }}$ Feb 2022; Accepted: 12 $2^{\text {th }}$ Feb 2022; Available online: $25^{\text {th }}$ Feb 2022

How to Cite This Article: Al-Ghezi, M.K.S, Ahmed, R.T., Chaichan, M.T (2022) The Influence of Temperature and Irradiance on Performance of the photovoltaic panel in the Middle of Iraq. International Journal of Renewable Energy Development, 11(2), 501-513

https://doi.org/10.14710/ijred.2022.43713

\section{Introduction}

The traditional energy sources, most notably fossil fuels, constitute the main source of energy for our planet, reaching $80 \%$ of the total resources at the present time (AlGhezi et al., 2022). Non-renewable sources provide us with energy, but in return cause an increase in greenhouse gases and pollutants in the atmosphere (Bamehr and Sabetghadam, 2021). Electrical energy production obtained by burning fossil fuels leads to an increase in the emission of $\mathrm{CO}_{2}$ and other gases such as methane, $\mathrm{NO}_{\mathrm{x}}$ and unburnt hydrocarbons that lead to environmental pollution and the emergence of global warming (Fayad et al., 2021). There is a bright spot calling for optimism, which is the limited of fossil fuels. These fuels are estimated to be depleted during the next few decades, or their stocks will drop significantly. This situation will lead to curbing dependence on it in the near future for energy production (Chaichan et al., 2018; Moafaq, 2019). Global energy consumption is expected to reach 30 terawatts in 2050 compared to 10 terawatts at the present time. This requires the production of 20 terawatts of new energy (AlGhezi et al., 2022; Abdelhafidi et al., 2021). Among the best plans put forward is to use large-scale PV systems, in addition to other renewable resources, contribute to the production of an additional 10 terawatts of electricity. Through the use of hydrogen in transportation, which can also be used to produce heat for industrial and domestic uses. In this way the required 10 terawatts can be saved. This scenario will make the use of photovoltaic energy a matter of urgency to make up the shortfall in global energy supply in the near future (Omar and Mahmoud, 2021; Islam and Hossain, 2022). Humans have used solar energy since ancient times in various fields. Solar energy applications passed through multiple stages using many technologies until it reached the invention of PV cells (Moafaq et al., 2021). This technology today is the most promising technology in our time. PV technology uses the photoelectric effect property, which allows it to convert the incoming solar radiation directly into electricity (Moafaq et al., 2022). The photovoltaic cells are characterized by being made of semi-conductive materials in which silicon

\footnotetext{
* Corresponding author: moafaq.k.shiea@uotechnology.edu.iq
} 
element is used extensively. When the sun's rays fall on the surface of the photoelectric cell, an area called the depletion region will form at the $\mathrm{p}-\mathrm{n}$ junction to transfer the energy carried by the incoming photon from the solar radiation to the electron in the photoelectric cell. If the electron gets enough energy, it will be released to the conduction level (Jatoi et al., 2018). In this way an electric potential difference will be generated across the depletion region resulting in an electric field. This process is repeated between the photons and the electrons, leading ultimately to the production of electricity (Simon et al., 2021). There are many parameters that affect the work of photovoltaic cells. The most important of which are climatic parameters. The solar radiation intensity variation, as well as increasing PV cell temperature reduce these devices ablity to produce electricity at steady and stable rates (Al-Waeli et al, 2016).

Any project that produces electricity using photovoltaic modules depends mainly on the energy generated by these panels. For this project to be economically feasible, it requires increasing the efficiency of these modules to obtain the highest possible output energy. There is an inherent obstacle to the use of photovoltaics, which is the limited efficiency and high manufacturing cost. Therefore, research efforts have been intensified to find methods to increase efficiency and reduce manufacturing cost (Chaichan and Kazem, 2018; Fayad and Dhahad, 2021). There are several factors that affect the solar panel efficiency can be studied, the most prominent of which are the solar radiation intensity and the PV panel temperature, which are closely related to each other and directly affect the efficiency and the output power of the solar panel (Sangeetha et al., 2020). Usually, photovoltaic panels are manufactured under standard test conditions (STC), where it indicates that one degree increase of temperature causes a decrease in the PV panel efficiency by 0.004-0.005 (Natarajan et al., 2011). In the actual operating conditions of PV modules, these panels are not likely to operate under standard conditions. Therefore, when initiating the construction and installation of PV systems, real external conditions and exposure to different environmental conditions must be taken into account (Al-Nasser et al, 2020). When the solar radiation falls on the surface of the solar cell, $80 \%$ of the radiation energy is converted into thermal energy, which accumulates inside the solar cell (Zhang et al., 2014; Roshen, 2017). Thermal energy accumulated in the PV panels causes two losses, the first loss is that this percentage of radiation is wasted in form of thermal energy inside the solar panel and cannot be utilized. The second negative disadvantage is accumulated heat, which raises the temperature of the photovoltaic cells, leading to a decrease in its efficiency (Kazem et al., 2020).

Many previous studies have searched the effect of the solar radiation fluctuation and the volatility of the temperature on the performance of PV panels. Suwapaet and Boonla (2014) compared the behavior of different types of photovoltaics with increasing temperature. Their study proved that monocrystalline silicon panels are less efficient than amorphous PV panels provided it operate at similar conditions and high temperature. The study also investigated the effects of solar radiation on the PV performance. When solar radiation was $600 \mathrm{~W} / \mathrm{m}^{2}$, amorphous PV panels produced greater power than monocrystalline silicon at the same temperature increase. Ike (2013) discussed the influence of weather parameters such as ambient temperature on the overall performance of the photovoltaic panels. The author claimed that there is an indirect correlation between the ambient temperature and the output energy of the system. Also, the study recommended the necessity to take care of the passage of an air stream through the panels when designing. Dash and Gupta (2015) investigated the relationship between temperature and the power produced by different types of photovoltaic panels. The authors used the temperature coefficient as a reference function for PV output power. It was concluded that the highest average output power loss was when using monocrystalline panels, as it reached $0.446 \%$ per degree Celsius. Swapnil et al. (2013) analyzed many studies and concluded that the temperature has a linear relationship with the photoelectric conversion procedures as well as the output power of the photoelectric modules. The researcher showed that numerical parameters depend on both matter and system at the same time.

Chander et al. (2015) simulated the effect of increasing the photovoltaic (PV) panel temperature on the overall performance independent of the effect of solar radiation intensity. The researchers used a constantintensity light that was projected on a photovoltaic panel. The researchers concluded that increasing the temperature has an inverse effect with respect to fill factor (FF), open circuit voltage $\left(\mathrm{V}_{\mathrm{oc}}\right)$, and maximum power $\left(\mathrm{P}_{\max }\right)$. Whereas, the effect of temperature increase was direct with respect to the short circuit current $\left(\mathrm{I}_{\mathrm{sc}}\right)$.

Khaled et al. (2015) studied the effect of shading on the maximum output power of the PV panels and the concomitant decrease in efficiency. The study concluded that increasing the PV temperature reduces its maximum output power. Tarak et al. (2012) analyzed the PV modules and how they performed under different weather conditions using basic semiconductor equations. Temaneh and Mukwekwe (2015) concluded that the increase in PV panel temperature is most important factor that causes the increase in its power losses. It was mentioned that the 37.8 $\mathrm{kW}$ photovoltaic systems operated daily in duration of 12 hours had recorded losses of $14.6 \mathrm{kWh}$ due to the effect of temperature raise. The study proved that an increase of one kelvin in temperature caused a loss of power up to $0.31 \%$. Zhe et al. (2021) investigated the effect of changing solar radiation intensity on the characteristics and performance of PV modules.

Many researchers have used mathematical models to linearly predict the effect of variables such as radiation intensity and temperature in several regions of the world. In such studies, the results are compared with the expected results of the artificial neural network, and the validity of the results is verified by comparing them with the results of practical experiments (Al-Waeli et al, 2019). In Oman, Yousif et al. (2019) examined and analyzed weather data for the period from 1991 to 2015, in order to predict accurate future weather information and to encode the appropriate climatic dimensions for solar electricity generation. Therefore, the study focused on accurate prediction of temperature and relative humidity.

In current paper, the effects of the solar radiation fluctuation and the temperature increase on the overall performance of the solar panels have been analyzed. The 
relationships among these variables and basic parameters of PV panels such as short circuit current, open circuit voltage, output power, efficiency and fill factor were studied. There may be many international studies similar to this study, but it is for the conditions of other countries, not for the weather conditions in Iraq rather than for the conditions of the city of Baghdad, the capital. Baghdad is characterized by continental weather, very hot in summer and very cold in winter. This city is also exposed to waves of relative humidity, but it is limited, and the wind speed is very moderate, not exceeding $3 \mathrm{~m} / \mathrm{s}$ most days of the year. To the knowledge of the researchers, a similar study to this study has not been conducted localy or internationally before.

\section{The Modeling of Photovoltaic Cell}

The simplest mathematical model of the equivalent circuit of a photovoltaic cell can be described with an ideal current source connected in parallel with an ideal diode (Solmetric, 2016), as shown in figure 1. The current generated by the photons, represented by the ideal current source, it is usually stable at a certain temperature and light radiation (Gabriel and Odai, 2021). The relationship that relates current to both voltage and temperature is shown in Equation 1:

$$
I=I_{p h}-I_{o}\left(e^{\frac{q\left(V+I R_{S}\right)}{m k T}}-1\right)-\frac{V+I R_{S}}{R_{p}}
$$

Where $I, I_{p h}, I_{o}, q, V, R_{S}, m, k, T$ and $R_{p}$ are the current generated by the photons (ideal current), current generated by the light radiation (photocurrent), the diode saturation current, the electronic charge $=1.6 \times 10^{-19}$, the voltage of the PV unit, resistance of the cell series, quality factor of the diode, the Boltzmann's constant $=1.38 \times 10^{-23}$ $\mathrm{J} / \mathrm{K}$, the ambient temperature in Kelvin, the cell (shunt) resistance respectively.

The PV cell's performance characteristics can be analyzed by five main parameters of the solar module, namely, the short circuit current, the open circuit voltage, maximum power, efficiency and fill factor. These charactristics can be determined by studying the I-V curve (Khan et al., 2021). In an open circuit, $\mathrm{I}=0, \mathrm{~V}=\mathrm{V}_{\text {oc }}$ (Tiwari and Dubey, 2010), and in a short circuit, $\mathrm{I}=\mathrm{I}_{\mathrm{sc}}, \mathrm{V}=0$ (Rodrigues et al., 2011), by substituting these values into the equation 1 , the equation becomes as:

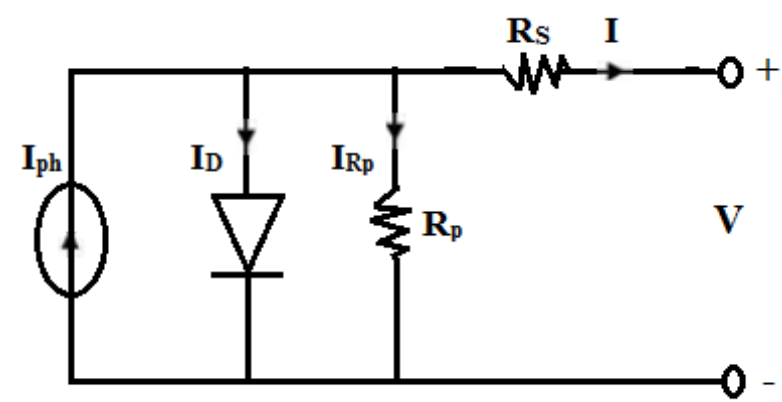

Fig. 1 The schematic diagram of the PV cell equivalent electric circuit.

$$
\begin{aligned}
& 0=I_{p h}-I_{o}\left(e^{\frac{q V o c}{m k T}}-1\right)-\frac{V_{o c}}{R_{p}} \\
& I_{s c}=I_{p h}-I_{o}\left(e^{\frac{q I_{s c} R_{S}}{m k T}}-1\right)-\frac{I_{s c} R_{S}}{R_{p}}
\end{aligned}
$$

From equations 2 and 3 :

$$
\begin{aligned}
& V_{o c}=\frac{m k T}{q} \ln \left(\frac{I_{s c}}{I_{o}}+1\right), \mathrm{I}=0 \\
& I_{s c}=I_{p h}-I_{o}\left(e^{\frac{q I_{s c} R_{S}}{m k T}}-1\right)-\frac{I_{s c} R_{S}}{R_{p}}, \mathrm{~V}=0
\end{aligned}
$$

The fill factor is defined as the ratio between the actual and ideal maximum output powers of the PV cell. It is one of the parameters that indicate the quality of the PV cell (Bhalchandra and Sadawarte, 2015), and can be obtained as:

$$
F F=\frac{P_{\max }}{V_{o c} I_{s c}}=\frac{I_{\max } V_{\max }}{I_{s c} V_{o c}}
$$

The efficiency is defined as the ratio of the electrical output power of the PV cell to the energy of solar radiation falling on the surface of that cell (Soteris, 2014), and can be expressed as:

$$
\eta=\frac{I_{S c} \times V_{o c} \times F F}{G \times A_{c}}
$$

Where $G$ is the solar radiation $\left(\mathrm{W} / \mathrm{m}^{2}\right)$ and $\mathrm{A}_{\mathrm{c}}$ is the solar cell area $\left(\mathrm{m}^{2}\right)$.

\section{Material and Method}

The present study was conducted under the conditions of Baghdad city. Baghdad is the capital of Iraq and located in the middle of Iraq at $33.34 \mathrm{~N}^{\circ}$ latitude, $44.40 \mathrm{E}^{\circ}$ longitude, and $41 \mathrm{~m}$ above sea level. The study included two paths for obtaining and comparing results. The first path, was using PVsyst software to simulate the work of photovoltaic panels. This program provides the possibility of access to the basic parameters to evaluate the overall performance of PV panels. Some data were entered as inputs to PVsyst software. The most important input data were the longitude and latitude and the location of the study, in the current case it was Baghdad city. Also, the temperature, solar radiation value, model and the type of the PV panel and some other parameters were entered. This simulation was implemented at standard test conditions (STC), which are $25^{\circ} \mathrm{C}$ ambient temperature, $1000 \mathrm{~W} / \mathrm{m}^{2}$ solar irradiance and air mass 1.5 (Zainal et al., 2016). Since the standard test conditions are really unrealistic, various data were entered, which are closer to the real operating conditions. Through the simulation program, many data were obtained, the most important of which are: short circuit current, output power, open circuit voltage, and efficiency. Important relationships can be found to evaluate the overall performance of the PV panels, as the efficiency variation with solar radiation intensity and temperature, voltages with current, voltages with the output power, in addition to other less important relationships.

As for the other path of this study, it included analysis of the overall performance of the PV panel. The variance in electrical properties and output power were 
analysed as a result of the influence of many parameters. These parameters were: contrasting solar radiation and increasing the operating temperature through exposure to real outdoor operating conditions and conducting the practical experiments.

\section{Experimental Setup}

The studied system was installed on the roof of the Energy and Renewable Energy Technology Center (ERETC) at the University of Technology which is located approximately in middle of Baghdad city. A 120 W polycrystalline silicon photovoltaic panel was installed with a tilt angle of $37^{\circ}$ from the horizon facing south. The building of ERETC consists of four floors, with a height of $14 \mathrm{~m}$. There are no elevated structures nearby, which ensures the absence of shade on the PV panel used and that it is exposed to direct sunlight throughout the test period. It is crucial that a PV panel with characteristics similar to those used in the PVsyst simulation software is used, in order to obtain a logical comparison of the performance behavior in both cases. The specifications of the PV panel are listed in Table 1.

Several measurement devices were used to obtain the parameters of the photovoltaic panel at the outdoor experimental site. The various parameters of the PV panel were measured from 8:00 am to 5:00 pm, where the readings were recorded every 15 minutes. An YK-80AM type anemometer was used to measure wind speed. Data logging solar power meter, type - ISO-TECH ISM 410 was used to measure the intensity of solar radiation. Multiple electrical parameters output of the PV panel were recorded using multimeter type-Proskit MT-1210. Three thermal sensors were installed on the back side, at the top, middle and bottom of PV panel in order to measure the average operating temperature. The used thermocouples were type $\mathrm{k}$, which can measure a temperature range between -200 to $1260^{\circ} \mathrm{C}$. The ambient temperature was measured by thermometer placed in the shade.

Table 1

The specifications of the PV panel

\begin{tabular}{lc} 
Typical power (Watts) at STC & $120 \mathrm{~W}$ \\
Nominal rated voltage at STC & $12 \mathrm{~V}$ \\
Maximum power (Watts) & $120.6 \mathrm{~W}$ \\
Tolerance (\%) & $+/-3 \%$ \\
Voltage at max power & $17.8 \mathrm{~V}$ \\
Current at max power & $6.73 \mathrm{~A}$ \\
Open circuit voltage & $22 \mathrm{~V}$ \\
Short circuit current & $7.52 \mathrm{~A}$ \\
Dimensions & $1205 \times 675 \times 42(+/-2$ \\
& $\mathrm{mm})$ \\
\hline
\end{tabular}

\section{Results and Discussion}

\subsection{The output performance behavior of the photovoltaic panel in the simulation PVsyst program}

Figure 2 represents the relationship between the current, voltage and output power at a constant temperature of $25{ }^{\circ} \mathrm{C}$ and a variable solar radiation between 200 and $1000 \mathrm{~W} / \mathrm{m}^{2}$. This is a hypothetical case that cannot be applied under the real operating conditions. The maximum values of the current and voltage were 7.52 A, $22 \mathrm{~V}$, respectively at solar radiation intensity of 1000 $\mathrm{W} / \mathrm{m}^{2}$. While their minimum values were $1.51 \mathrm{~A}, 20.35 \mathrm{~V}$, respectively at a solar radiation of $200 \mathrm{~W} / \mathrm{m}^{2}$. The output power of PV panel increased with the solar radiation increase, as it decreased to $23.4 \mathrm{~W}$ at solar radiation 200 $\mathrm{W} / \mathrm{m}^{2}$ while it was $120 \mathrm{~W}$ at $1000 \mathrm{~W} / \mathrm{m}^{2}$. Here it must be emphasized that the current, voltage and output power of the photovoltaic panel were increased with the increase of solar radiation with the temperature remaining constant. The best performance of the photovoltaic panel was under standard test conditions (STC). These results are consistent with the studies done by (Belkassmi et al., 2017; Bouraiou et al., 2015; Kachhiya et al., 2011).

Figures 3 and 4 show the performance test of PV panel at a constant solar radiation while the temperature was changed. The behavior of the current-voltage (I-V) and power-voltage $(\mathrm{P}-\mathrm{V})$ curves were studied at different temperatures. It is clear that the relationship between current and temperature was a direct relationship, although the increase in current was slight when the temperature was increased. The curves analysis shows the inverse relationship of the voltage with temperature, as the voltage values gradually decreased with increasing temperature at constant solar radiation of $1000 \mathrm{~W} / \mathrm{m}^{2}$. The voltage value at the temperature of $25^{\circ} \mathrm{C}$ was $22 \mathrm{~V}$ while it was decreased to $18.8 \mathrm{~V}$ when the temperature was increased to $70{ }^{\circ} \mathrm{C}$. When the temperature of the PV panel reached $35^{\circ} \mathrm{C}$, it was noticed that the value of the output power decreased to $115.7 \mathrm{~W}$ while it was $120.6 \mathrm{~W}$ at $25^{\circ} \mathrm{C}$. In other words, an increase in the temperature of $10^{\circ} \mathrm{C}$ caused a decrease in the output power by approximately $4.08 \%$. Through the overall analysis of the P-V curve, it was found that when the temperature rise to $70{ }^{\circ} \mathrm{C}$, the output power decreased to $98.3 \mathrm{~W}$ while it was $120.6 \mathrm{~W}$ at $25^{\circ} \mathrm{C}$. This result indicates that the output power decreased by $0.41 \%$ for each one degree temperature rise. These results agree with the works done by (Tobnaghi and Naderi, 2015; Arjyadhara et al., 2013).

There is a strong relationship between the ambient temperature and the solar radiation intensity. As it is known, the temperature increases with the increase in the value of solar radiation. Although the increase in ambient temperature leads to an increase in the operating temperature of the PV panel, which leads to a decline in the output power. However, this increase in temperature is accompanied by a significant increase in the solar radiation intensity, which enhances the production of the solar panel. Usually, the increase in the output power of the PV panel as a result of the increase in solar radiation is greater than the deterioration in the output power due to the increase of temperature associated with the increase in solar radiation. Before conducting the simulation, the average ambient temperature was measured during the time of practical experiments using a thermometer, it was 
set at $34{ }^{\circ} \mathrm{C}$. An anemometer device was used to measure the average wind speed in the outdoors on the roof of the work building and its value was approximately $3 \mathrm{~m} / \mathrm{sec}$. Average ambient temperature and wind speed rate measured were used as inputs to the simulation PVsyst software. Figure 5 highlights the P-V curves characteristics of the PV panel at constant ambient temperature and variable values of solar radiation, as well as a constant value of the heat transfer coefficient. The heat transfer coefficient (U) was calculated using a simplified equation including the effect of wind speed $(\mathrm{U}=5.7+3.8 \mathrm{~V})$, and its value was $17 \mathrm{~W} / \mathrm{m}^{2} \mathrm{~K}$.

STC has an irradiance value of $1000 \mathrm{~W} / \mathrm{m}^{2}$ and a temperature of $25^{\circ} \mathrm{C}$, which is almost impossible to achieve under real operating conditions. As it can be seen in Figure 5 , the maximum radiation value of $1000 \mathrm{~W} / \mathrm{m}^{2}$ is accompanied by the highest value of the temperature about $82{ }^{\circ} \mathrm{C}$ while the lowest value of the temperature is $43^{\circ} \mathrm{C}$ at the minimum radiation of $200 \mathrm{~W} / \mathrm{m}^{2}$. Temperature increased by $46.56 \%$ due to the impact of increased solar radiation between minimum and maximum values. One of the most important factors that determine the quality of the performance of PV panel is the output power. It was found that the output power increases with the increase in the value of the solar radiation. This increase is not ideal due to the energy loss resulted from the increase in temperature, as can be seen from the curves in Fig. 5. These results agree with study done by (Ugwuoke and Okeke, 2012).

Figure 6 examines the effect of temperature contrast on the efficiency of the PV panel for a certain solar radiation range. The highest efficiency of the photovoltaic panel can be obtained at the maximum solar radiation provided that the temperature is in minimum value, as is the case in the standard test conditions. By looking at Figure 6, it can be said that the highest value of the PV panel efficiency was $12.18 \%$ at solar radiation of 1000 $\mathrm{W} / \mathrm{m}^{2}$ and $\mathrm{PV}$ temperature of $25^{\circ} \mathrm{C}$, which is similar to the standard test conditions. The lowest efficiency value of $9.95 \%$ was found at $70^{\circ} \mathrm{C}$ and solar radiation of $200 \mathrm{~W} / \mathrm{m}^{2}$. As the temperature increased, the efficiency of the photovoltaic panel deteriorated, and its values were $10.7 \%$, $11.3 \%$ and $11.7 \%$ at temperature $55^{\circ} \mathrm{C}, 45^{\circ} \mathrm{C}$, and $35^{\circ} \mathrm{C}$, respectively. This behavior of efficiency with temperature agreed with the study conducted by (Tobnaghi et al., 2013).

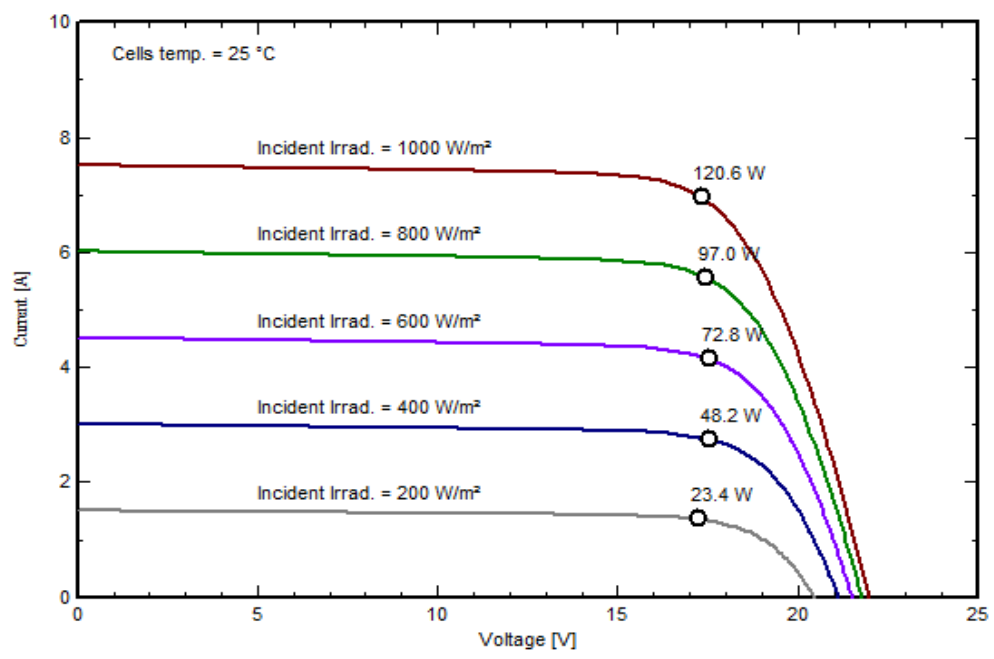

Fig. 2 The output performance of the PV panel at constant temperature of the PV panel, $25^{\circ} \mathrm{C}$ and different solar irradiance.

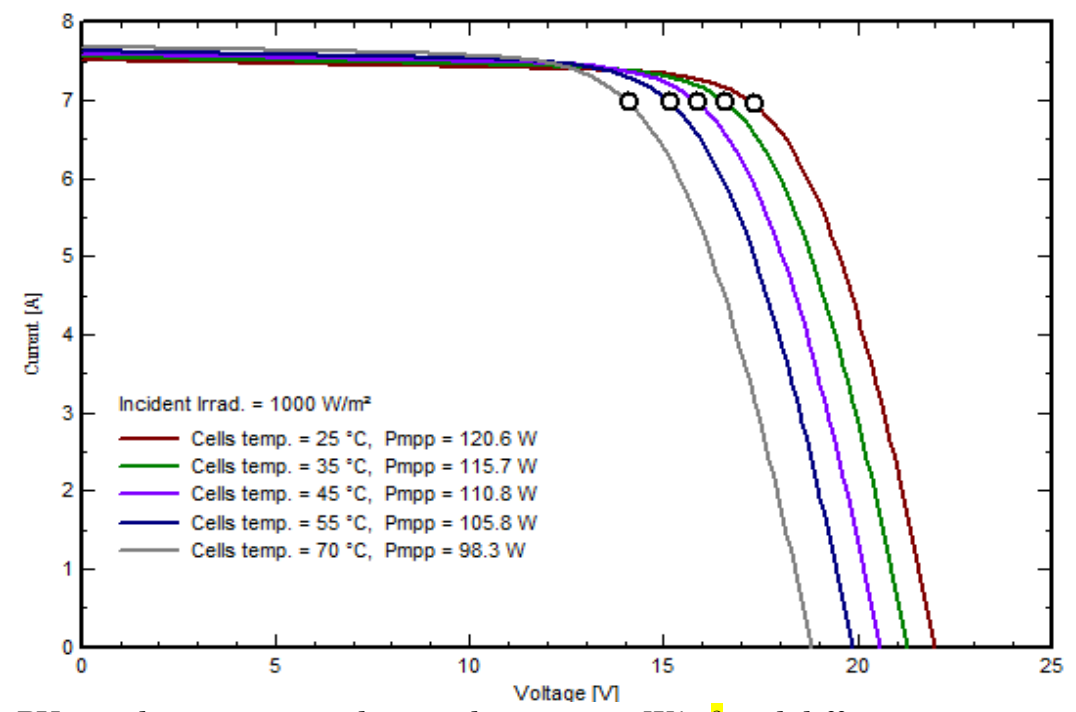

Fig. 3 The I-V curve of the PV panel at constant solar irradiance, $1000 \mathrm{~W} / \mathrm{m}^{2}$ and different temperature of the PV panel. 
Citation: Al-Ghezi, M.K.S, Ahmed, R.T., Chaichan, M.T (2022) The Influence of Temperature and Irradiance on Performance of the photovoltaic panel in the Middle of Iraq. Int. Journal of Renewable Energy Development, 11(2), 501-513; di: 10.14710/ijred.2022.43713

$506 \mid$

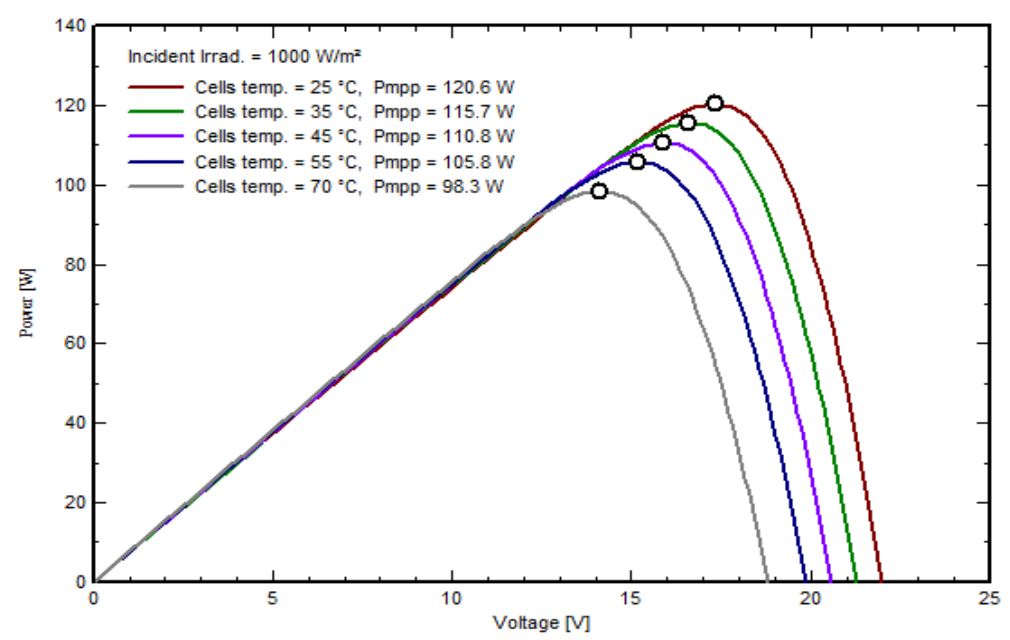

Fig. 4 The P-V curve of the PV panel at constant solar irradiance, $1000 \mathrm{~W} / \mathrm{m}^{2}$ and different temperature of the PV panel.

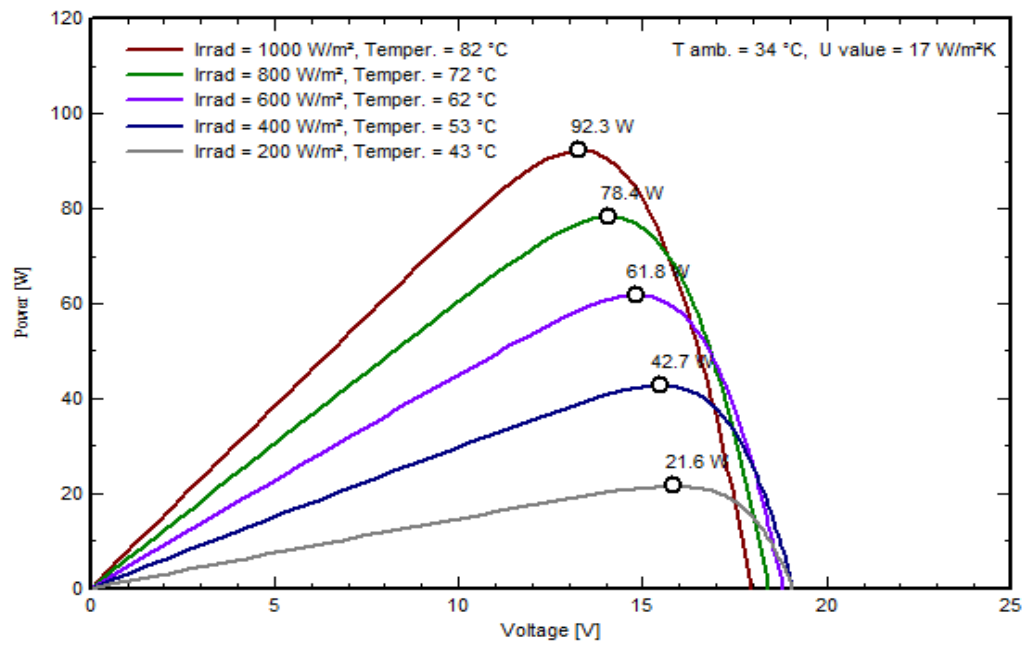

Fig. 5 The P-V curve characteristics of the PV panel at the constant ambient temperature and heat transfer coefficient, and various solar irradiance and PV panel temperature.

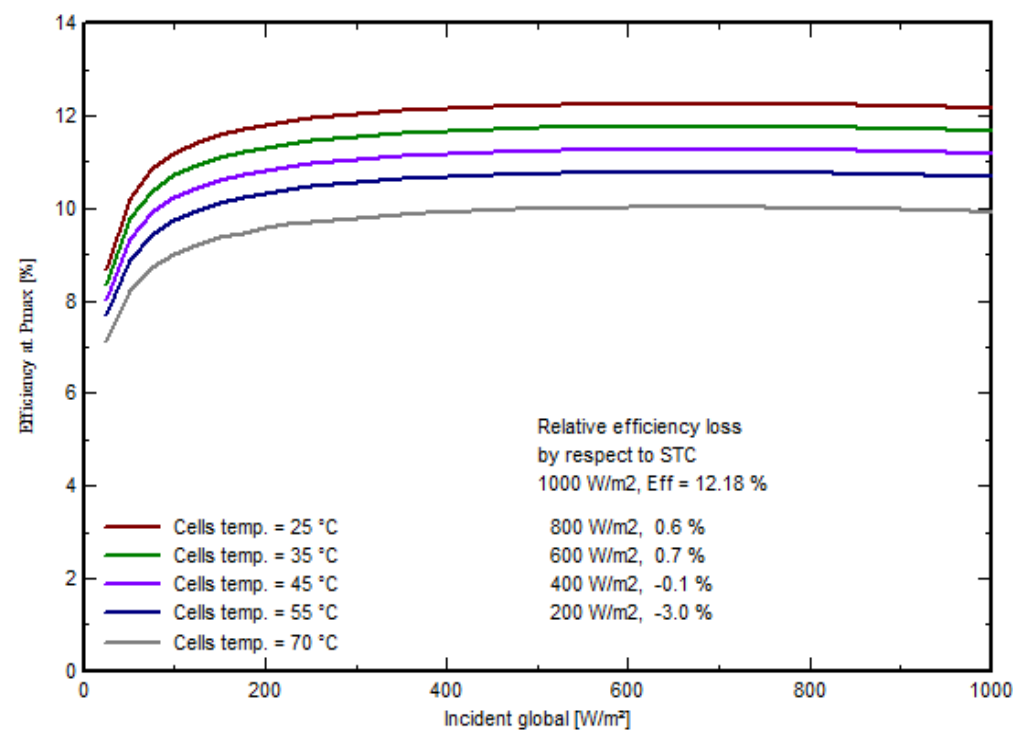

Fig. 6 The Efficiency curve characteristics of the PV panel at various PV panel temperatures and solar radiation. 
5.2. The output performance behavior of the PV panel in outdoor conditions: Experimental results

The solar radiation intensity is one of the most important factors affecting the output power of the PV panel. It is expected that the output performance of PV panel will be improved with the increase in the solar radiation intensity. To study the behavior of $\mathrm{PV}$ panel in the real operating environment, it was necessary to measure the solar radiation intensity. This issue was achieved using data logging solar power meter. Solar radiation was measured from 8:00 am to 5:00 pm, with one reading every 15 minutes at the experimental site. Figure 7 illustrates the variation of solar radiation during daytime hours. It is easy to note that the solar radiation is very high throughout the day, reaching more than 800
$\mathrm{W} / \mathrm{m}^{2}$ from 9:15 am until 2:45 $\mathrm{pm}$. The maximum value of the measured radiation was at $2: 45 \mathrm{pm}$, reaching 1195.235 $\mathrm{W} / \mathrm{m}^{2}$, while the lowest value was $158.755 \mathrm{~W} / \mathrm{m}^{2}$ at $5 \mathrm{pm}$. It is clear that the solar radiation curve during the day was regular and does not contain any anomalies. During the period of outdoors experiments, the sky was clear, free of clouds, and the solar radiation intensity was high. The lack of high buildings in the vicinity also prevented shading on the photovoltaic panels. It can be emphasized that the study site and the city of Baghdad in general possess great and promising potentials for the establishment of projects based on solar energy, the most important of which are photovoltaic systems. These results agree with study done by (Al-Ghezi et al., 2022).

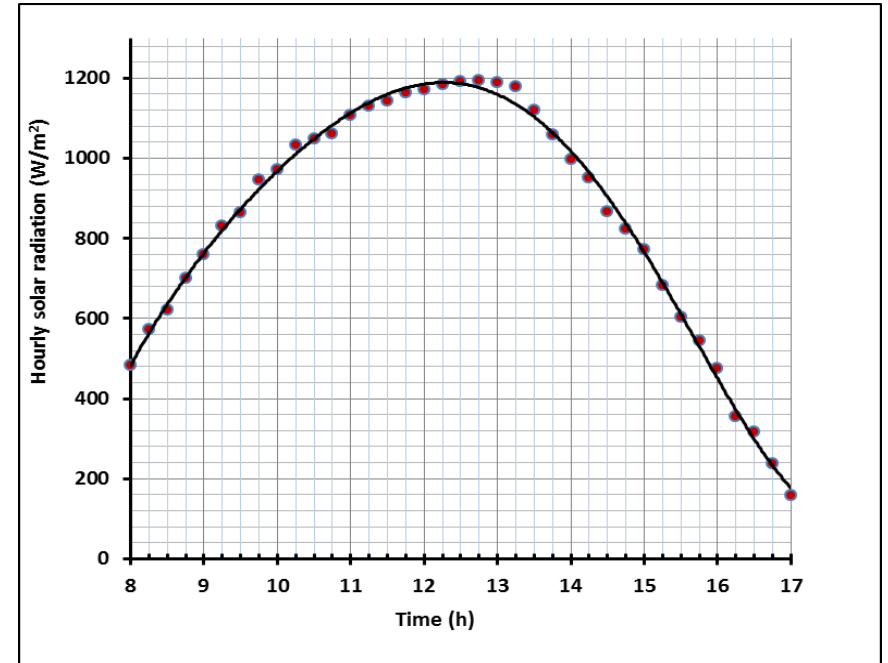

Fig. 7 Variation of solar radiation during the experimental day

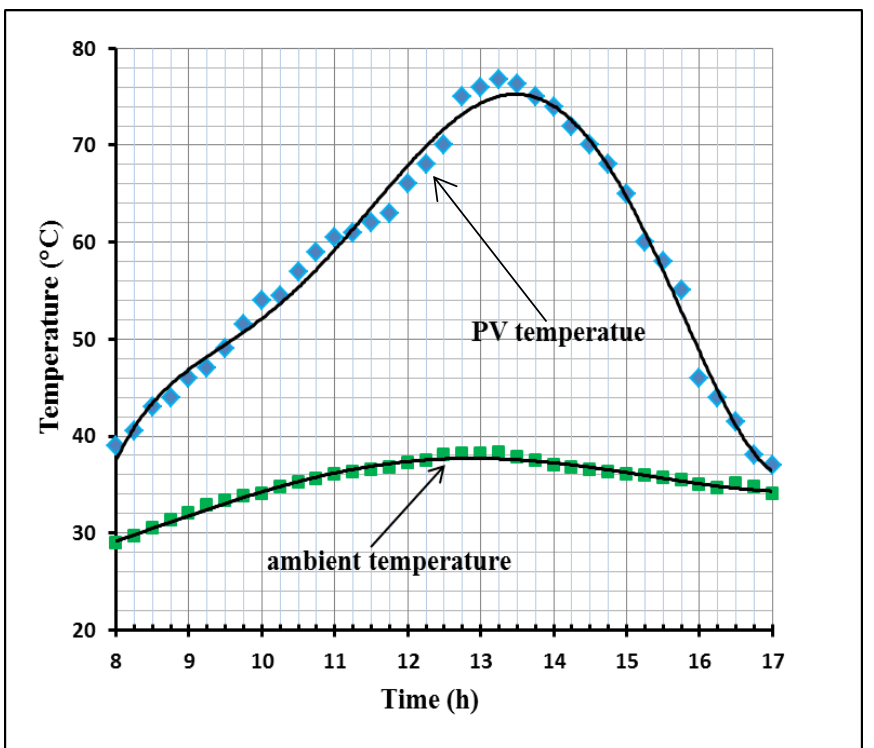

Fig. 8 Variation of ambient temperature and the PV panel temperature during the experimental day. 
There is a close relationship between the solar radiation intensity and the ambient temperature, and thus the temperature of the PV panel. This is evident from the observation of Figure 8. Obviously, when the solar radiation was increased, both the ambient and PV temperatures were increased. It was noted that the temperature was somewhat low at the start of the experiment and increased with the passage of time and reached its peak during rush hour and then decreased again to reach its lowest values at the afternoon. The lowest solar radiation intensity at the morning period was at 8:00 am with a value of $484.064 \mathrm{~W} / \mathrm{m}^{2}$, accompanied by an ambient temperature of $29^{\circ} \mathrm{C}$. Ambient temperature continued to increase until it reached a peak of $38.23^{\circ} \mathrm{C}$ with $1178 \mathrm{~W} / \mathrm{m}^{2}$ at $1: 15 \mathrm{pm}$. The lowest value of the ambient temperature was $34^{\circ} \mathrm{C}$ at the afternoon with $158.755 \mathrm{~W} / \mathrm{m}^{2}$ solar intensity at $5: 00 \mathrm{pm}$. The average ambient temperature during the day through the experiments period was $34.216^{\circ} \mathrm{C}$. The temperature of the photovoltaic panel behaved similarly to the ambient temperature, as both of them increased with increasing solar radiation. However, there was a large difference between them in terms of values. This difference was increased during the peak hours of the day. The difference between the ambient temperature and the PV panel temperature is very important because the bulk of the energy produced by the PV panel occurs when the difference between the two temperatures is large. By contemplating at figure 8 , the highest value of the PV panel temperature was $76.8^{\circ} \mathrm{C}$ with $1178 \mathrm{~W} / \mathrm{m}^{2}$ at $1: 15 \mathrm{pm}$ and the lowest value was $37^{\circ} \mathrm{C}$ with minimum solar radiation of $158.755 \mathrm{~W} / \mathrm{m}^{2}$ at $5: 00 \mathrm{pm}$. The average $\mathrm{PV}$ temperature during the day for the experiment period was $57.89^{\circ} \mathrm{C}$. The relatively large difference between the temperature of the PV panel and the ambient is attributed to several reasons, the most important of which is that the wind speed in the city of Baghdad is low throughout the year and the sun's brightness is high. As well as the low heat transfer coefficient between air and PV body, which reduces heat transfer from the surface of the hot PV panel to the ambient air.

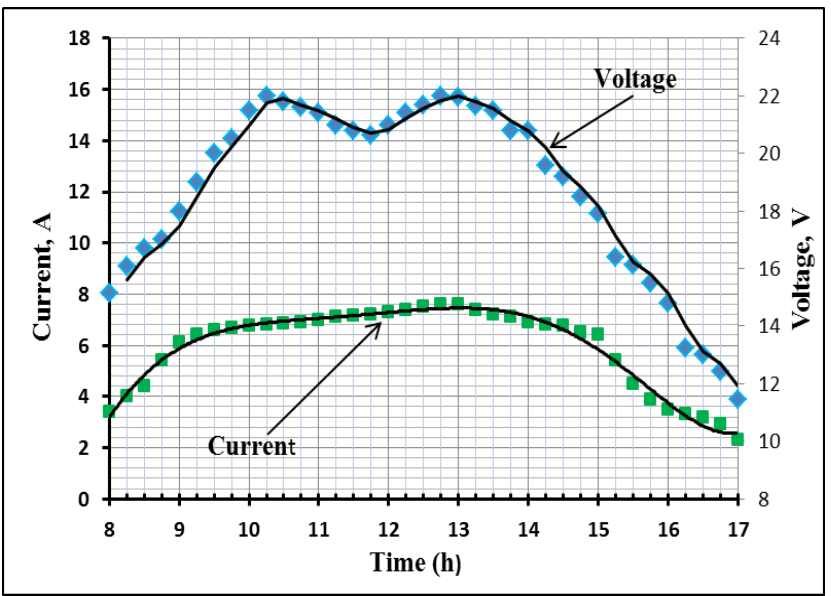

Fig.9 The effect of the PV panel temperature on the characteristics of current and voltage.

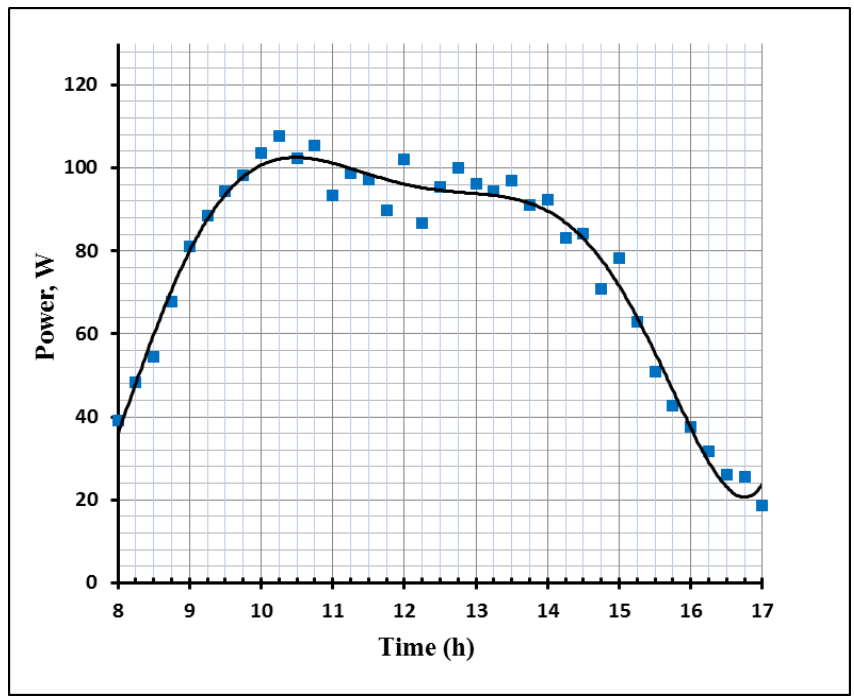

Fig.10 The effect of the PV panel temperature on the characteristics of the out power curve. 
Figure 9 shows the current-voltage (I-V) curve, where it was necessary to measure the current and voltage to calculate the PV panel output power. I-V cirve is one of the most important characteristics of the photovoltaic panel. Figure 9 includes the distribution of current and voltage measured throughout the day during the experiments period, i.e. from 8:00 am to 5:00 pm. It is clear that the current was increased with the increase in solar radiation that was accompanied by an increase in the PV panel temperature. The increase in current is more pronounced for the period from 9:00 am to 3:15 pm. The maximum measured value of the current was $7.2 \mathrm{~A}$ at 11:45 am with PV temperature of $63^{\circ} \mathrm{C}$ and solar radiation of $1164 \mathrm{~W} / \mathrm{m}^{2}$. The minimum value of the current was recorded at $2.3 \mathrm{~A}$ at 5:00 pm with PV temperature of $37^{\circ} \mathrm{C}$ and solar radiation of $158.755 \mathrm{~W} / \mathrm{m}^{2}$. To understand more about the effect of increasing the PV panel temperature on the current produced, it is necessary to compare two cases in which the values of solar radiation are equal or at least close at different PV panel temperatures. For example, at 9:30 am, the solar radiation value was $864 \mathrm{~W} / \mathrm{m}^{2}$, and the PV panel temperature was $49{ }^{\circ} \mathrm{C}$. It was found that the current was $6.6 \mathrm{~A}$. At $2: 30 \mathrm{pm}$, the value of solar radiation was $868 \mathrm{~W} / \mathrm{m}^{2}$ and the temperature of the PV panel was 70 ${ }^{\circ} \mathrm{C}$. The generated current was about $6.75 \mathrm{~A}$. This difference between the two measured current values is due to the effect of increasing the PV panel temperature, which is directly proportional to the value of current. In other words, the high PV panel temperature means that the panel has absorbed a greater amount of solar radiation falling on the panel surface. This condition leads to greater amounts of current generation and vice versa. Also, if the $\mathrm{PV}$ panel is exposed to the same amount of radiation at varying PV temperatures, it produces more amperes at the higher temperature. Figure 9 includes the behavior of the output voltage of the PV panel throughout the day during the experiment period too. As it shows the effect of PV panel temperature combined with solar radiation on the output voltage of the panel. It is clear from the curve that the output voltage was increased with the increase in solar radiation from 8:00-10:15 am despite the increase in PV panel temperature. This behavior is attributed to the fact that the increase in the voltage is much affected by the large increase in solar radiation. In the same time, the decadence of the output voltage as a result of the increase in the PV panel temperature is less than the increase by the solar radiation effect. Also, the increase in temperature was not large to be sufficient for the deterioration of the voltage to large levels. The output voltage was $15.16 \mathrm{~V}$ at 8:00 am when the solar radiation was $484.064 \mathrm{~W} / \mathrm{m}^{2}$ and the PV panel temperature was $39^{\circ} \mathrm{C}$. The output voltage reached $22 \mathrm{~V}$ at 10:15 am when the solar radiation was $1034 \mathrm{~W} / \mathrm{m}^{2}$ and the panel temperature was $54.5^{\circ} \mathrm{C}$. The effect of the PV panel temperature on the output voltage is evident from 10:30 am until $12 \mathrm{pm}$. The output voltage started to decrease despite the increase in solar radiation. The output voltage was about $21.8 \mathrm{~V}$ at 10:30 am when solar radiation was $1048 \mathrm{~W} / \mathrm{m}^{2}$ and the $\mathrm{PV}$ panel temperature was $57{ }^{\circ} \mathrm{C}$. However, the output voltage reached $21 \mathrm{~V}$ with solar radiation of $1171.32 \mathrm{~W} / \mathrm{m}^{2}$ and panel's temperature of $66^{\circ} \mathrm{C}$ at $12: 00 \mathrm{pm}$. The decrease in the output voltage was due to the fact that the PV panel had witnessed a significant increase in its temperature accompanied by a small change in solar radiation during this period. The output voltage was increased from 12:15 1:00 pm due to a large increase in solar radiation accompanied by a small increase in temperature. The voltage difference returns to decrease again from 1:15 to 5:00 pm due to the decrease in solar radiation while the temperature remaining somewhat high. For further clarification on the effect of the temperature of the PV panel on the output voltage, the output voltage was compared under equal or close values for solar radiation and different PV temperatures. The output voltage was at a value of $21.6 \mathrm{~V}$ when the solar radiation was $1061 \mathrm{~W} / \mathrm{m}^{2}$ and the panel temperature was $59{ }^{\circ} \mathrm{C}$ at $10: 45$ am. At $1: 45$ $\mathrm{pm}$ the voltage was $20.8 \mathrm{~V}$ with solar radiation $1060 \mathrm{~W} / \mathrm{m}^{2}$ and the temperature was $75^{\circ} \mathrm{C}$. These results agree with study done by (Fesharaki et al., 2011).

Figure 10 shows the behavior of the output power curve of the PV panel throughout the day during the experiment. There is a close relationship between current and voltage on the one hand, and the output energy of the PV panel on the other. Since both current and voltage are affected by the increase in the temperature of the PV panel, the output power is also affected as a result of the temperature variation. It was found that the maximum PV output power produced was $106 \mathrm{~W}$ at 10:15 am and 54.5 ${ }^{\circ} \mathrm{C}$, whereas the minimum value of the output power was recorded about $18.57 \mathrm{~W}$ at 5:00 pm with temperature of $37^{\circ} \mathrm{C}$. It is not possible to reach the maximum power output of the PV panel used $(120 \mathrm{~W})$ during the experiments due to the influence of several factors. The most important of which is the increase in temperature. In addition to the panel specifications estimated under standard test conditions as explained previously. In general, from the output power curve, it was found that the value of the output power was increased from 8:00 am to 10:15 am due to the large increase in solar radiation accompanied by a slight rise in the $\mathrm{PV}$ temperature. When the solar radiation was $864 \mathrm{~W} / \mathrm{m}^{2}$ and temperature $49{ }^{\circ} \mathrm{C}$ at 9:30 am, the output power was $94.50 \mathrm{~W}$. At $2: 30 \mathrm{pm}$, the radiation was $868 \mathrm{~W} / \mathrm{m}^{2}$ and the temperature was $70^{\circ} \mathrm{C}$, the output power was $84.03 \mathrm{~W}$. Although the solar radiation is almost the same, the output power has decreased due to the negative temperature effect. This behavior of the output power with temperature agrees with the results of (Zia et al., 2015).

Figure 11 describes an important parameter of the solar panel, which is the efficiency. It is noted that the efficiency was increased from 8:00 am to 10:30 am and then started to decline until 1:15 pm. After 2:00 pm, it was increased again until the end of the experiment time, i.e. at 5:00 pm. It is not necessary that the maximum efficiency be associated with the highest value of solar radiation, but rather the opposite. At the peak period from 12:00 to 3:00 $\mathrm{pm}$, the minimum values of efficiency were recorded, when the solar radiation is at its maximum values. This result can be referred to the effect of increasing the temperature on efficiency, as during this period the temperature reached its maximum values. The maximum efficiencies were recorded in the morning period from 9:00 to 10:00 am. Also, another maximum efficiencies were recorded for the period from 4:30-5:00 pm, where the PV temperatures are moderated at these times. For example, at 9:30 am, the solar radiation $864 \mathrm{~W} / \mathrm{m}^{2}$ and the temperature $49{ }^{\circ} \mathrm{C}$, the efficiency was $11 \%$. At $2: 30 \mathrm{pm}$, the radiation was 868 $\mathrm{W} / \mathrm{m}^{2}$ and the temperature was $70{ }^{\circ} \mathrm{C}$, the efficiency was $7.6 \%$. This behavior shows the negative effect of the PV 
panel temperature increase on the efficiency, despite the convergence of the solar radiation values. This behavior of the efficiency with temperature agrees with (Kabbani and Mohamed, 2021) results.

Figure 12 describes the variation of the fill factor of the PV panel throughout the day during the experiment period. The fill factor is an important parameter to determine the quality of the PV panels. Usually, the PV panels fill factor ranges from 0.5-0.82. The PV panels are considered to be of good quality when the fill factor is 0.7 or above. It was found that the PV fill factor is more than 0.7 throughout the experiment periods, except for the period between 11:45 am - 2:15 pm when the sun is at its peak. This is due to the increase temperature of the photovoltaic panel during this period. This means that the fill factor is inversely proportional to the PV panel temperature increase. The maximum value of the fill factor was recorded at 8:00 am when the temperature of the photovoltaic panel was $39^{\circ} \mathrm{C}$ with a value of 0.81 while the minimum value was found at $12: 30 \mathrm{pm}$ with a value of 0.635 at a temperature of $70^{\circ} \mathrm{C}$. This behavior of the fill factor with temperature agrees with the works of (Bhalchandra and Sadawarte, 2015; Kabbani and Mohamed, 2021).

For the purpose of validating the experimental results, they were compared with the outputs of the simulation software; the comparison of the results is listed in Table 2.

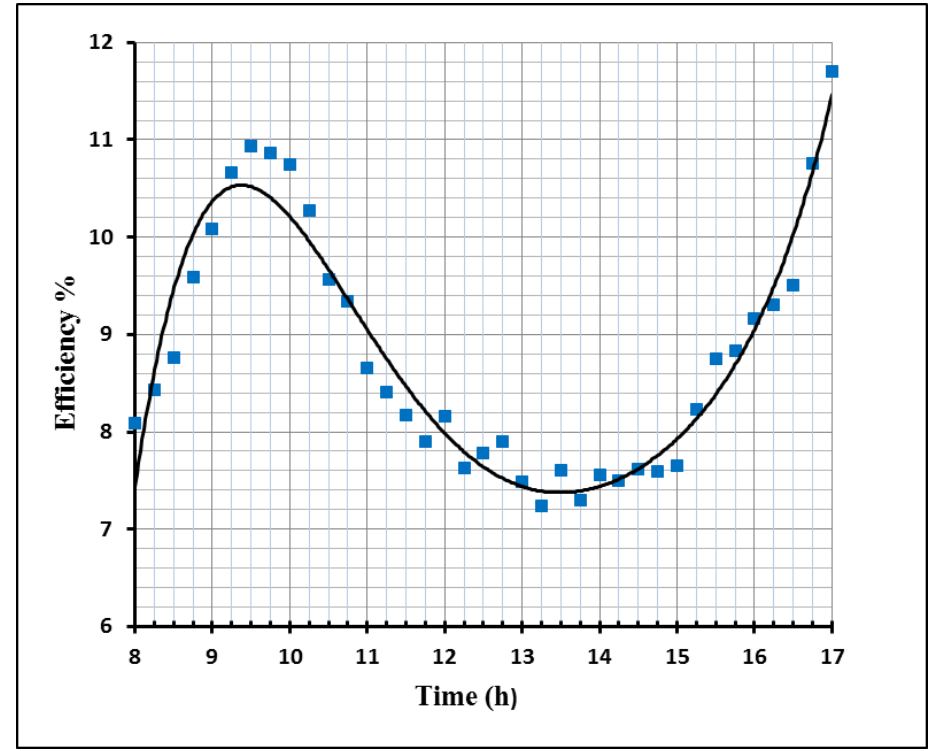

Fig.11 The effect of the PV panel temperature on the characteristics of efficiency curve.

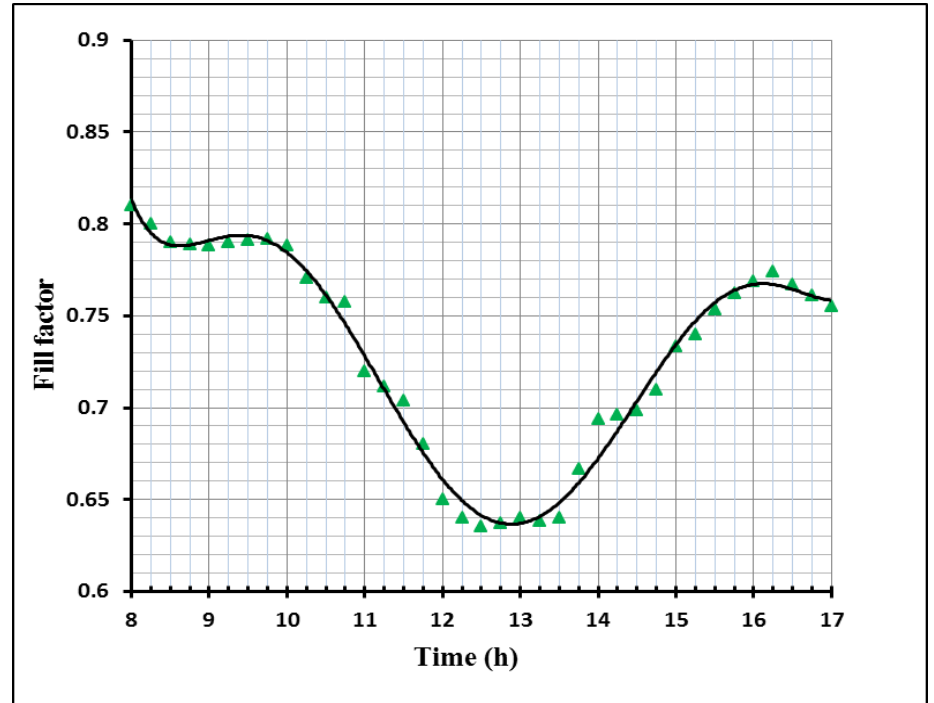

Fig.12 The effect of the PV panel temperature on the fill factor. 
Table 2

Comparison between the experimental results and the outputs of the simulation software.

\begin{tabular}{ccc}
\hline Parameter & Simulation software results & Experimental results \\
\hline For constant temperature and the solar radiation was increased by $50 \%$ \\
\hline Current & increased by $43.17 \%$ & increased by $42.56 \%$ \\
Voltage & increased by $4.650 \%$ & increased by $4.390 \%$ \\
Output power & increased by $49.76 \%$ & increased by $48.88 \%$ \\
\hline For constant solar radiation and the temperature was increased by $1^{\circ} \mathrm{C}$ \\
\hline Current & increased by $0.073 \%$ & increased by $0.068 \%$ \\
Voltage & decreased by $0.320 \%$ & decreased by $0.340 \%$ \\
Output power & decreased by $0.439 \%$ & decreased by $0.489 \%$ \\
Efficiency & decreased by $0.408 \%$ & decreased by $0.586 \%$ \\
\hline
\end{tabular}

\section{Conclusion}

In the current study, the effect of solar radiation and operating temperatures on the parameters of photovoltaic panels is explained. Two paths were taken to obtain the results, namely, the use of PVsyst simulation software and practical outdoor experiments. Efficiency values were recorded during the peak of the sun when the maximum values of solar radiation existed. The experimental study and the simulation program agreed that increasing the operating temperature had a negative impact on the performance of the photovoltaic panel in general. Increasing the temperature of the solar panel by $1^{\circ} \mathrm{C}$ causes the current to rise by about $0.068 \%$, and the voltage drop by about $0.34 \%$ which reduces the output power by $0.489 \%$ causing the electrical efficiency to deteriorate by about $0.586 \%$. Increasing the temperature also causes the filling factor to decrease. A method has been adopted to evaluate the effect of solar radiation and operating temperature on the parameters of the PV panel. In this method, two equal or close values of solar radiation and different operating temperatures at two different times during the day were taken and the behavior of each parameter of the PV panel was studied separately. It is important to know that the specifications of photovoltaic panels provided by manufacturers under Standard Test Conditions (STC) differ from what was achieved under external conditions. So, when constructing a project, it is necessary to rely on data provided by field studies to determine efficiency, output power and size of panels PV. It is very important to develop this study in the near future by including the influence of other weather factors such as wind speed, relative humidity and dust.

\section{References}

Abdelhafidi, N., Bachari, N.E.I. \& Abdelhafidi, Z. (2021). Estimation of solar radiation using stepwise multiple linear regression with principal component analysis in Algeria. Meteorol Atmos Phys, 133, 205-216; https://doi.org/10.1007/s00703-020-00739-0

Ahmed-Hamdi R. T. (2017) Solar cell system simulation using Matlab-Simulink. Kurdistan Journal for Applied Research (KJAR), 2(1); https://doi.org/10.24017/science.2017.1.5

Al-Ghezi, M.K. (2019). Study the Maximum Solar Radiation by Determining the Best Direction of the Solar Collectors.
International Research Journal of Advanced Engineering and Science, 4(3), 42-44

Al-Ghezi, M.K., Abass, K.I., Salam, A.Q., Jawad R.S. \& Kazem, H.A. (2021). The possibilities of using nano-CuO as coolants for PVT system: An experimental study. Journal of Physics: Conference Series, 1973(1), 012123; https://doi.org/10.1088/1742-6596/1973/1/012123

Al-Ghezi, M.K., Mahmoud, B.K., Alnasser, T. and Chaichan, M.T., 2022. A Comparative Study of Regression Models and Meteorological Parameters to Estimate the Global Solar Radiation on a Horizontal Surface for Baghdad City, Iraq. International Journal of Renewable Energy Development, 11(1). https://doi.org/10.14710/ijred.2022.38493

Alnasser, T.M., Mahdy, A.M., Abass, K.I., Chaichan, M.T. and Kazem, H.A. (2020) Impact of Dust Ingredient on Photovoltaic Performance: An Experimental Study. Solar Energy. 195, 651-659. https://doi.org/10.1016/j.solener.2019.12.008

Arjyadhara P, Ali S.M, Chitralekha J. (2013) Analysis of solar PV cell performance with changing irradiance and temperature, International Journal of Engineering and Computer Science. 2(1), 214-20.

Al-Waeli, A.H., Sopian, K., Kazem, H.A. and Chaichan, M.T. (2016) Photovoltaic Solar Thermal (PV/T) Collectors Past, Present and Future: A Review. International Journal of Applied Engineering Research. 11(22), 10757-10765.

Al-Waeli, A.H., Kazem, H.A., Yousif, J.H., Chaichan, M.T. and Sopian, K. (2019) Mathematical and Neural Network Models for Predicting the Electrical Performance of a PV/T System. International Journal of Energy Research. 43(14), 8100-8117. https://doi.org/10.1002/er.4807

Bamehr, S. \& Sabetghadam, S. (2021). Estimation of global solar radiation data based on satellite-derived atmospheric parameters over the urban area of Mashhad, Iran. Environmental Science and Pollution Research, 28(6), 71677179; https://doi.org/10.1007/s11356-020-11003-8

Belkassmi, Y., Rafiki, A., Gueraoui, K., Elmaimouni, L., Tata, O., \& Hassanain, N. (2017). Modeling and Simulation of Photovoltaic Module Based on One Diode Model Using Matlab/Simulink, Proceedings of the International Conference on Engineering \& MIS (ICEMIS), pp. 1-6; https://doi.org/10.1109/icemis.2017.8272965

Bhalchandra C, Sadawarte Y. (2015) The factors affecting the performance of solar cell. International conference on Quality upgrading in Engineering, Science and Technology, International Journal of Computer Applications; http://citeseerx.ist.psu.edu/viewdoc/download;jsessionid=7D 
59BE3DE5CA89178C7DEF8EFD42D382?doi=10.1.1.742.1 259\&rep=rep1\&type $=$ pdf

Bouraiou, A., Hamouda, M., Chaker, A., Sadok, M., Mostefaoui, M. and Lachtar, S. (2015) Modeling and simulation of photovoltaic module and array based on one and two diode model using matlab/Simulink. Energy Procedia, Vol. 74, pp. 864-877; https://doi.org/10.1016/j.egypro.2015.07.822

Chaichan, M.T., Kazem, H.A. \& Abed, T.A. (2018) Traffic and outdoor air pollution levels near highways in Baghdad, Iraq. Environ Dev Sustain 20, 589-603. https://doi.org/10.1007/s10668-016-9900-x

Chaichan, M.T., Kazem, H. A. (2018) Generating Electricity Using Photovoltaic Solar Plants in Iraq, Springer, ISBN: 978-3319-75030-9; https://doi.org/10.1007/978-3-319-75031-6

Chander S., Purohit A., Sharma A., Arvind, Nehra S.P. and Dhaka M.S. (2015) A study on photovoltaic parameters of monocrystalline silicon solar cell with cell temperature. Energy Reports, 1, 104-109; https://doi.org/10.1016/j.egyr.2015.03.004

Dash, P., \& Gupta, N.C. (2015). Effect of Temperature on Power Output from Different Commercially available Photovoltaic Modules. International Journal of Engineering Research and Applications, 5(1), 148-151.

Dubey, S., Sarvaiya, J.N. \& Seshadri, B. (2013) Temperature Dependent Photovoltaic (PV) Efficiency and Its Effect on PV Production in the World - A Review, Energy Procedia, 33(1), 311-321; https://doi.org/10.1016/j.egypro.2013.05.072

Fayad, M.A., Al-Salihi, H.A., Dhahad, H.A., Mohammed, F.M. and Al-Ogidi, B.R. (2021) Effect of post-injection and alternative fuels on combustion, emissions and soot nanoparticles characteristics in a common-rail direct injection diesel engine. Energy Sources, Part A: Recovery, Utilization, and Environmental Effects, https://doi.org/10.1080/15567036.2021.1970292.

Fayad, M.A. and Dhahad, H.A., 2021. Effects of adding aluminum oxide nanoparticles to butanol-diesel blends on performance, particulate matter, and emission characteristics of diesel engine. Fuel, 286, p.119363, https://doi.org/10.1016/j.fuel.2020.119363.

Fesharaki VJ, Dehghani M, Fesharaki JJ. (2011) The effect of temperature on photovoltaic cell efficiency. International Conference on Emerging Trends in Energy Conservation, pp.1-6.

Gabriel Takyi and Odai Godlove Laryea,. (2021) Comparative study of the performance of solar photovoltaic module technologies installed in Kumasi, Ghana, in Sub-Saharan Africa. Scientific African, 13, e00877; https://doi.org/10.1016/j.sciaf.2021.e00877

Ike, C. U. (2013) The Effect of Temperature on the Performance of A Photovoltaic Solar System In Eastern Nigeria, International Journal of Engineering and Science, 3(13), 1014.

Islam, M. and Hossain, M. (2022) Economic Feasibility of Solar Irrigation Pumps: A Study of Northern Bangladesh. International Journal of Renewable Energy Development, 11(1) https://doi.org/10.14710/ijred.2022.38469

Jatoi, A., Samo, S. R. and Jakhrani, A. (2018) Influence of Temperature on Electrical Characteristics of Di dfferent Photovoltaic Module Technologies. International Journal of Renewable Energy Development, 7(2), 85-91. https://doi.org/10.14710/ijred.7.2.85-91

Kabbani, A., \& Mohamed Shaik, H. (2021). PV Cell Parameters Modeling and Temperature Effect Analysis. International Journal of Renewable Energy Development, 10(3), 563-571. https://doi.org/10.14710/ijred.2021.33845

Kachhiya, K., Lokhande, M. and Patel, M. (2011) Matlab/simulink model of solar PV module and MPPT algorithm. National Conference on Recent Trends in Engineering and Technology
Kazem, H.A., Al-Waeli, A.H., Chaichan, M.T., Al-Waeli, K.H., AlAasam, A.B. and Sopian, K. 2020. Evaluation and Comparison of Different Flow Configurations PVT Systems in Oman: A Numerical and Experimental Investigation. Solar Energy. 208, 58-88.

https://doi.org/10.1016/j.solener.2020.07.078

Khaled Matter1, Hala J. El-Khozondar, Rifa J. El-Khozondar, Teuvo Suntio,. (2015) Matlab/Simulink Modeling to study the effect of partially shaded condition on Photovoltaic array's Maximum Power Point. International Research Journal of Engineering and Technology (IRJET), 2(2), 697703

Khan MAI, Khan MI, Kazim AH, Shabir A, Riaz F, Mustafa N, Javed H, Raza A, Hussain M and Salman CA (2021) An Experimental and Comparative Performance Evaluation of a Hybrid Photovoltaic Thermoelectric System. Front. Energy Res., 9:722514; https://doi.org/10.3389/fenrg.2021.722514

Natarajan S., Mallick T., Katz M. and Weingaertner S. (2011) Numerical investigations of solar cell temperature for photovoltaic concentrator system with and without passive cooling arrangements. International Journal of Thermal Sciences, 50(12), 2514-2521; https://doi.org/10.1016/j.ijthermalsci.2011.06.014

Li, Z., Yang, J. \& Dezfuli, P.A.N. (2021) Study on the Influence of Light Intensity on the Performance of Solar Cell. International Journal of Photoenergy, 6648739; https://doi.org/10.1155/2021/6648739

Omar, M.A. and Mahmoud, M.M. (2021) Improvement Approach for Matching PV-Array and Inverter of Grid Connected PV Systems Verified by a Case Study. Int. Journal of Renewable Energy Development, 10(4), https://doi.org/10.14710/ijred.2021.36082

Rodrigues E.G., Melicio, R., Mendes, V.F. \& Catalao, J.S. (2011) Simulation of a Solar Cell Considering Single Diode Equivalent Circuit Model. Renewable Energies and Power Quality Journal, 1(9), 369-373; https://doi.org/10.24084/repqj09.339

Sangeetha, M., Manigandan, S., Chaichan, M.T. and Kumar, V. (2020) Progress of MWCNT, $\mathrm{Al} 2 \mathrm{O} 3$, and $\mathrm{CuO}$ with water in enhancing the photovoltaic thermal system. International Journal of Energy Research.44(2), 821-832. https://doi.org/10.1002/er.4905

Simon, M. Sze., Yiming, Li., Kwok, K. Ng. (2021) Physics of Semiconductor Devices, 944 p., 4th Edition, John Wiley, Interscience, New York, ISBN: 978-1-119-42911-1.

Solmetric. Guide to Interpreting I-V Curves; (2016), Available at: http://resources.solmetric.com/get/Guide\%20to\%20Interpre ting201v\%20curves.pdf

Soteris A. Kalogirou,. (2014) Solar energy engineering (Second Edition): photovoltaic systems: chapter 9. Academic Press; $p$. 481-540; https://doi.org/10.1016/B978-0-12-397270-5.00009$\underline{1}$

Suwapaet N. and Boonla P. (2014) The investigation of produced power output during high operating temperature occurrences of monocrystalline and amorphous photovoltaic modules. Energy Procedia, 52(1), 459- 465; https://doi.org/10.1016/j.egypro.2014.07.098

Salmi, T., Bouzguenda, M., Gastli, A. \& Masmoudi, A. (2012) MATLAB/Simulink Based Modelling of Solar Photovoltaic Cell. International Journal of Renewable Energy Research, 2(2), 213-218.

Temaneh-Nyah, C. and Mukwekwe, L. (2015) An investigation on the effect of operating temperature on power output of the photovoltaic system at University of Namibia Faculty of Engineering and I.T campus. Third International Conference on Digital Information, Networking, and Wireless Communications (DINWC), pp. 22-29, https://doi.org/10.1109/DINWC.2015.7054211 
Tiwari, G.N. \& Dubey, S. (2010) Fundamental of photovoltaic modules and their applications. Royal Society of Chemistry; 1st edition, 424 pages; ISBN:1849730202.

Tobnaghi, D.M., Madatov, R., Naderi, D. (2013) The Effect of Temperature on Electrical Parameters of Solar Cells. International Journal of Advance Research in Electrical, Electronics and Instrumentation Engineering, 2(12), 64046407.

Tobnaghi, D.M., Naderi, D. (2015) The effect of solar radiation and temperature on solar cells performance. Extensive Journal of Applied Sciences. 3, 39-43.

Ugwuoke, P.E, Okeke, C.E. (2012) Performance assessment of Three Different PV Modules as a Function of Solar Insolation in South Eastern Nigeria. International Journal of Applied Science and Technology, 2(3), 319-327.

Yousif, J.H., Al-Balushi, H.A., Kazem, H.A. and Chaichan, M.T., (2019) Analysis and Forecasting of Weather Conditions in Oman for Renewable Energy Applications. Case Studies in Thermal
Engineering, 13,
https://doi.org/10.1016/j.csite.2018.11.006

100355.

Zhang, X., Shen, J., Xu, P., Zhao, X. and Xu, Y. (2014) SocioEconomic Performance of a Novel Solar Photovoltaic/LoopHeat-Pipe Heat Pump Water Heating System in Three Different Climatic Regions. Applied Energy, 135(1), 20-34. https://doi.org/10.1016/j.apenergy.2014.08.074

Zainal, N. A., Apen, A. \& Yusoff, A.R. (2016). Modelling of Photovoltaic Module Using Matlab Simulink. IOP Conference Series: Materials Science and Engineering,114, 012137; https://doi.org/10.1088/1757-899X/114/1/012137

Zia, R., Saleemi, F., Naseem, S. and Kayani, Z. (2015) Study the Efficiency of Single Crystal CdTe/ZnCdS Solar Cell at Various Temperatures and Illumination Levels. Energy Reports, 1, 58-61; https://doi.org/10.1016/j.egyr.2015.01.002 